\title{
Max Planck plans double blow to chemistry
}

Quirin Schiermeier, Munich

Two highly rated chemistry groups look set to become the first casualties of a budget freeze at Germany's Max Planck Society.

Nature has learned that plans to close the cosmochemistry and geochemistry departments at the Max Planck Institute for Chemistry in Mainz are expected to be approved by the society's ruling body in June - a move that some say would end Germany's involvement in top-quality science in these fields.

Up to 20 Max Planck research units are likely to shut down over the next few years. Peter Gruss, the society's president, said last November that such closures are unavoidable following the government's decision to freeze the society's budget at E1.2 billion (US $\$ 1.3$ billion) this year (see Nature 420, 452; 2002).

The departments are being dismantled partly because their present scientific directors are due to retire. Geochemist Albrecht Hofmann will step down in 2005 and Günther Lugmair, head of cosmochemistry, will follow suit in 2007. The Max Planck Society traditionally builds departments around individual researchers, and always evaluates the future of a unit when its head leaves.

The Institute for Chemistry has proposed compensating for the closures by expanding its activities in atmospheric and climate research, with a special emphasis on remote satellite sensing. This new research structure has been agreed by a Max Planck committee, and is expected to be officially approved at a meeting of the society's senate in June.

But German researchers are worried by the plans. There are few other cosmochemistry and geochemistry groups in Germany, and the chemistry institute is widely acknowledged as one of Europe's premier centres for studies of the chemistry of the Earth's mantle and crust.

The cosmochemistry department also has an outstanding reputation in its own right. Lugmair and his group study the decay products of radionuclides found in meteorites to investigate planetary formation in the early Solar System. They operate one of the world's only two nanometre-resolution ion microprobes, devices that can detect tiny amounts of certain types of isotope. The E2-million facility was installed at the institute only two years ago. The department is also involved in planetary missions planned by NASA and the European Space Agency.

"The closures would basically end Germany's presence in cosmochemistry and geochemistry," says Alex Halliday, a geochemist at the Swiss Federal Institute of Technology in Zurich. Friedrich Seifert, a geophysicist at the Bavarian Research Institute for Experimental Geochemistry and Geophysics in Bayreuth, agrees. "It would be

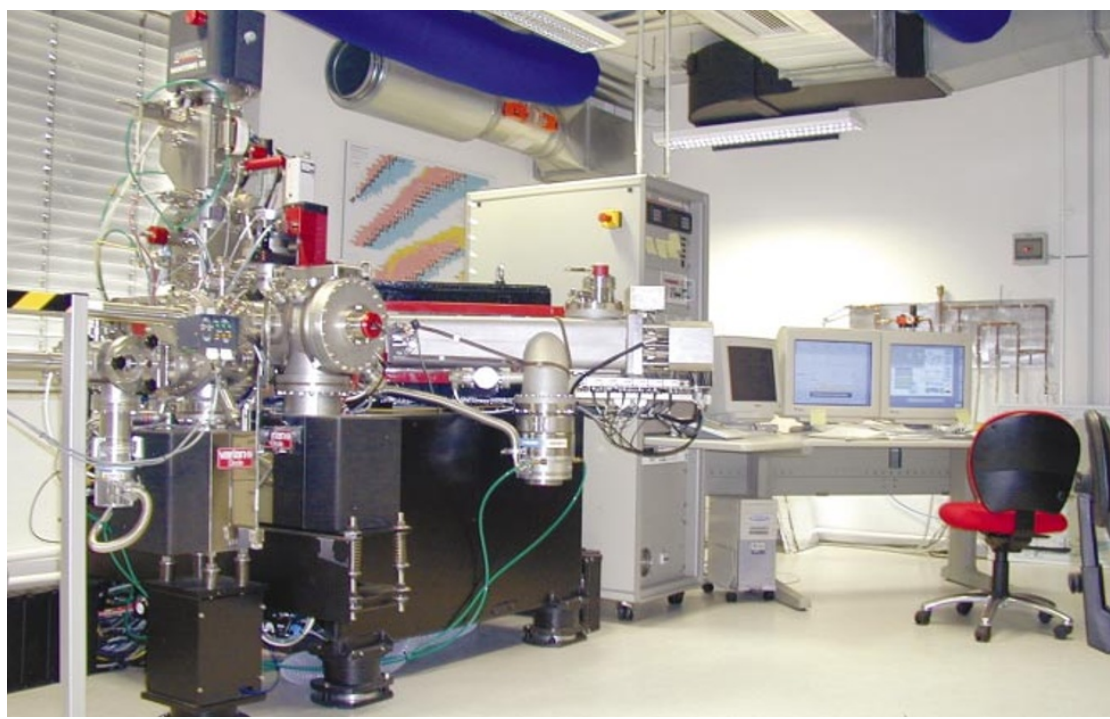

Unplugged: installed just two years ago, this E2-million ion microprobe may soon be without a home.

a disaster for the Earth sciences, not only in Germany," he says.

Bernd Wirsing, spokesman for the Max Planck Society, says that scientific factors remain the main consideration when implementing cuts. But Lugmair is disappointed that the society is not even trying to find possible successors for him and Hofmann.
Before he joined the society in 1996, Lugmair was head of a cosmochemistry group at the Scripps Institution of Oceanography in San Diego, California. "If I had known how things would develop here in Germany, I would probably not have come," he says. www.mpch-mainz.mpg.de/mpg/english/ index.html

\section{Danish biotech centre faces axe}

\section{Alison Abbott, Munich}

The Danish Biotechnology Instrument Center (DABIC), set up in 2000 to support research into genomics and proteomics, could face closure for want of funds to cover its running costs.

Based at the University of Southern Denmark in Odense, the centre was established with a three-year, $\mathrm{E} 18$-million (US\$20-million) grant. But it may now fall victim to a failed government policy.

In the late 1990s, the Danish government introduced about 50 highly specific research programmes, chosen by the national research councils, at a total cost of about $E \mathbf{2 7 0}$ million. The government had hoped that universities would take over the running costs of successful centres created under the scheme. But the universities say they cannot afford to do so, after the government and its successor (elected in 2001) failed to increase their budgets even in line with inflation.

The centres see little hope in turning to the national research councils for help. Although the councils are enjoying a temporary increase in funding - thanks to a share of profits from the sale of telecommunications licences - they cannot allocate the operational money needed to keep big centres going.

The DABIC is the largest of the centres. It involves 16 research groups across five universities, each of which bought expensive equipment and facilities. "Many of our groups will simply not be able to keep this equipment in service," says Peter Roepstorff, the centre's director. "Already we are losing people with expertise."

Jens Christian Djurhuus, head of Denmark's medical research council and director of the Institute for Experimental Clinical Research at the University of Aarhus, which hosts one of the DABIC's groups, says that his dual role makes him "ambivalent" about the situation. "The research councils were never particularly happy about having so many programmes with money earmarked for very specific projects, because there was not enough competition for each of them," he says. "But we were also unhappy when the former government lost interest in them, and we are worried about how the best ones can continue now." 